\title{
Changes of the Functional Capacity of Mesenchymal Stem Cells due to Aging or Age-Associated Disease - Implications for Clinical Applications and Donor Recruitment
}

\author{
Gerhard Thomas Laschober ${ }^{\mathrm{a}}$ \\ a Institute for Biomedical Aging Research, Austrian Academy of Sciences, \\ b Department of Cranio-Maxillofacial and Oral Surgery, University Hospital Innsbruck, Innsbruck, Austria
}

\author{
Key Words \\ Mesenchymal stem cells · Aging
}

\section{Summary}

In contrast to stem cells of embryonic origin, autologous tissue-specific stem cells are easier to introduce into the clinical practice. In this context, molecular and cellular changes, which alter tissue-specific stem cell properties with age, are of particular interest since elderly patients represent the main target group for cell-based therapies. The clinical use of mesenchymal stem cells is an emerging field, especially because this stem cell type appears to be amenable for the treatment of a large number of diseases, such as non-healing bone defects and fractures, inflammatory relief during arthritis, and the repair of suspensory ligament tears. More than that, mesenchymal stem cells provoke effective immune suppression in the context of graft-versus-host disease. Here, we present a comprehensive overview of the recent findings with special attention to age-related changes of mesenchymal stem cell properties and the consequential impact on tissue regeneration and repair, together with the current perception concerning their therapeutic application potential as well as the challenges associated with their clinical use.
Schlüsselwörter

Mesenchymale Stammzellen · Alterung

\section{Zusammenfassung}

Im Vergleich mit embryonalen Stammzellen sind autologe, gewebespezifische Stammzellen leichter in die klinische Praxis einzuführen. In diesem Zusammenhang sind aber molekulare und zelluläre Veränderungen, die dazu führen, dass sich Eigenschaften von gewebespezifischen Stammzellen mit dem Alter ändern, von besonderem Interesse, da ältere Patienten die Hauptzielgruppe für zellbasierte Therapien sind. Der klinische Einsatz von mesenchymalen Stammzellen ist ein prosperierendes Feld, weil gerade dieser Stammzelltyp für die Behandlung einer großen Zahl von Erkrankungen eingesetzt werden kann, z.B. bei nichtheilenden Knochendefekten und -frakturen, sowie bei der inflammatorischen Linderung im Verlauf einer Arthritis und der Wiederherstellung von Rissen des Ligamentum suspensorium. Darüber hinaus bewirken mesenchymale Stammzellen eine effektive Immunsuppression im Zusammenhang mit der Graftversus-Host-Erkrankung. Die vorliegende Arbeit gibt einen umfassenden Überblick der aktuellen Ergebnisse unter besonderer Berücksichtigung von altersabhängigen Veränderungen von mesenchymalen Stammzellen und dem daraus folgenden Einfluss auf Geweberegeneration. Darüber hinaus wird der aktuelle Stand hinsichtlich der therapeutischen Anwendungsmöglichkeiten von mesenchymalen Stammzellen und der Herausforderungen bei deren klinischer Anwendung dargestellt.

\begin{tabular}{ll}
\hline KARGER & $\oplus$ 2008 S. Karger GmbH, Freiburg \\
$\begin{array}{l}\text { Fax +497614520714 } \\
\begin{array}{l}\text { E-mail Information@Karger.de } \\
\text { www.karger.com }\end{array}\end{array}$ & $\begin{array}{l}\text { Accessible online at: } \\
\text { www.karger.com/tmh }\end{array}$
\end{tabular}

Dr. Günter Lepperdinger 


\section{‘Mesenchymal Stem Cell': A Proper Term?}

This designation is used by many investigators. However up to recently, the definition of what a mesenchymal stem cell is has been sketchy. Most blood cell types emerge from mesodermal derivatives. Therefore, hematopoietic stem cells are of mesenchymal origin. In contrast however, 'mesenchymal' is by all rules assigned to non-hematopoietic cells. With respect to the predication 'stem cell', the most stringent condition is the long-term potential to self-renew, together with the potency of giving rise to progenitor cells which in due course differentiate to form one or more specialized somatic cell types. In fact, mesenchymal stromal cells from various tissues show a broad differentiation potential when cultured under specific conditions. Taken together, however, doubts about the appropriateness of the term 'mesenchymal stem cell' have been raised, in particular because it is scientifically inaccurate and potentially misleading. Instead, the term multipotential mesenchymal stromal cell (MSC) has been proposed [1]. It is generally accepted that MSC can provide the housing for stem cells and for various progenitor cell types such as hematopoietic stem cells together with its respective progeny as well as endothelial progenitor cells. There is reason to believe though that MSC also contain a rare population of naive cell types which are true mesenchymal stem cells.

\section{Characteristics of Uncommitted Mesenchymal Stromal Cells in Culture}

In much of the literature, adherent fibroblastoid cells from a variety of tissues are termed mesenchymal stem or progenitor cells. These cell isolates are heterogeneous. To put it bluntly, it is highly unlikely that they comprise of only one single mesenchymal cell type. Due to the fact that there has not been a distinct and universal antigenic definition of an MSC, analogous to CD34+ cells for hematopoietic stem cells, and as there is no universal assay around, analogous to hematopoietic re-population assays, novel methods for the isolation of MSC with both self-renewal and multipotential differentiation capacity have been and are still being developed. Arnold Caplan [2] was the first to propose the term 'mesenchymal stem cell' for an adherent fibroblastic cell isolated by Percoll density centrifugation that expresses antigens reactive with the monoclonal antibodies SH2 (CD105) and SH3 (CD73). Pittenger et al. [3] have reported that CD29, CD44, and CD90 are important determinants. Prockop et al. [4] discovered a subpopulation of MSC, termed RS cells, which exhibit enhanced proliferation rates and cannot be clearly distinguished from other adherent MSC solely by expression of specific surface markers. At the same time, Simmons et al. [5] described the so-called STRO-1 antibody, which identifies an immature population of mesenchymal cells. Ever since, many other determinants have been discovered [6]. Given these observa- tions, the following minimum specifications to generally define MSC have been proposed only recently by a group of peers in the field: i) plastic adherence when maintained in standard culture conditions; ii) expression of surface molecules CD105, CD73 and CD90, and lack of expression of CD45, CD34, CD14 or CD11b, CD79alpha or CD19 and HLA-DR; and last but not least iii) differentiation potential towards osteogenic, adipogenic and chondrogenic cell types in vitro [7].

\section{Adult Stem Cells in an Aging Organism}

Stem cells are often defined as cellular entities that are able to continuously self-renew through replication, while in parallel producing tissue-specific precursor cells. Still, it is not fully understood what regulates the capacity of stem cells to continuously replicate and what might be the prerequisites to successfully bring forth various cell types at the same time. Despite a lack of in-depth knowledge about many facts, stem cells hold tremendous promise for the treatment of a variety of diseases. In this respect there is reason to believe that, besides embryonic stem cells, also adult stem cells will become highly attractive assets for regenerative medicine. For example, adult stem cells may be employed in multiple ways to heal or regenerate damaged tissue. More than that, adult stem cells are most attractive since they can be auto-transplanted, i.e. obtained from and re-inserted into the same patient. Apparently, auto-transplantation of cells eliminates potential donor-host immune rejection and disease transmission issues. Therefore, there is an increasing number of methods being developed and utilized under the guise of 'adult stem cell therapy' to treat medical problems. Presently, the question is widely discussed whether adult stem cells are at risk to fail in clinical applications because they may be prone to cellular aging.

Interestingly, it is still an unresolved issue whether and to what extent adult stem cells can cope with intrinsic and/or extrinsic aging processes in the body. Furthermore, it is not clear whether stem cells in complex organisms with multiple, highly specialized organs have life spans that exceed that of the organism. Stem cells potentially face extremely long replicative histories, and in due course, they are therefore subject to damage from several intracellular and extracellular sources. Moreover, it is not only the inevitable process of cellular aging stem cells are afflicted with, but there are also pathological incidences that are associated with aging, e.g. age-associated diseases and frailty [8]. It is generally believed that over the years cumulative effects are responsible for the aging of tissues. In line with these assumptions, work performed by many research teams over the last few years has demonstrated that MSC face extrinsic and intrinsic aging. 
Fig. 1. Emergence of MSC diversity during life span. Early in life, most, if not all, uncommitted MSC exhibit multipotential differentiation capacity, and their developmental fate is tightly controlled. In due course, additional types of mesenchymal precursors emerge as stable subpopulations. The rate of cell death is gradually increasing ( $\mathrm{MSC}^{\text {dying }}$ ). Other MSC accumulate various forms of damage which cannot be compensated by cellular repair $\left(\mathrm{MSC}^{\text {degen }}\right)$. Due to an age-dependent change in the activity of bioactive differentiation cues, be it their respective availability or alterations in cellular response or because of chronic, systemic inflammation, a subpopulation of uncommitted MSC becomes manifest: predetermined mesenchymal precursors (MPC). In total, only little decline of mesenchymal progenitor cell numbers is envisaged at advanced age. However, the number of truly naive, multipotential MSC steadily declines.

\section{Mesenchymal Stromal Cell Aging}

In the special context of organismic aging, several laboratories have only recently embarked on the characterization of MSC, and thus the field is still in its infancy. As a sound basis it is generally accepted by now that MSC can be isolated from a number of fetal and adult tissues. Human trimester fetal MSC have been isolated from blood, liver, bone marrow [9], amniotic fluid [10], placenta [11], and cord blood [12]; these investigations are still ongoing. MSC from the early organism appear to be more naive when compared to their adult relatives [13,14]. Regarding MSC isolated form adult tissues, bone marrow-derived MSC are the best-studied [15-17]. Besides MSC, which are juxtaposed to trabecular bone [18,19], also those from adipose tissues come more and more into fashion [20]. Further sources are periosteum [21], synovium [22], blood vessels [23], tooth pulp of extracted teeth $[24,25]$, and other connective tissue types such as dermis and muscle [26]. Moreover, there are reports demonstrating the existence of MSC within peripheral blood. These results are debated though and are not always reproducible [27]. MSC isolated from different tissues and organs actually show a high resemblance of phenotypic characteristics. At this point, however, it appears most likely that all these cell variants are MSC that exhibit different propensities in proliferation and differentiation capacities. For example, a recent study demonstrated that human adipose tissue contains the highest number of MSC and umbilical cord blood the lowest. In turn, the latter come along with greatly enhanced proliferation capacity, whereas human bone marrow-derived MSC cease growth earlier [28]. Fetal MSC also appear to be less lineagecommitted than MSC from adult human individuals [29]. In consequence, it has been assumed that various vital stem cell properties of MSC, such as their tissue regenerative capacity, are by and large different. Limitations are as follows: MSC only divide a finite number of times; they accumulate genetic and epigenetic changes over time; MSC subtypes exhibit tissue-specific, imprinted differentiation capacity. It may further be that these limitations directly correlate with donor age, in particular that stem cell properties decline with age (fig. 1).

\section{Pool Size, Differentiation Capability in Older Age}

MSC can be selected from low-density mononuclear cell isolates based on their characteristics of tightly adhering to the plastic surface of the culture dish and of forming fibroblastic colonies. The respective number, also called colony-forming unit-fibroblastic (CFU-f), can be reliably estimated. Applying this method, there are presently conflicting results regarding the question whether MSC numbers change during life span. Some laboratories report that total CFU-f decrease with age [30-35], others find no significant decline [36-40]. One particular problem with this approach is that there is no agreement on a single, standardized protocol for MSC isolation as well as how to proceed with further analysis of the primary cell isolates. Another issue is that the primary cell isolates are, though at a varying extent, contaminated by other cells, in particular by hematopoietic cells. Lastly, single clones within the heterogeneous cultures exhibit greatly varying differentiation potential, which was demonstrated by in vitro cell cloning of human stromal cultures: only around $30 \%$ of the CFU-f are multipotential and can thus be considered true MSC [41]. In addition to the aforementioned observations, Muraglia et al. [42] reported that the number of bi- or tri-potential colonies declined with age. In line with this, and in particular regarding the osteogenic capacity of clonogenic MSC, many reports demonstrated a significant decrease in MSC numbers [43, 44]. Besides bone and bone marrow, potential sources of mesenchymal progenitor cells are muscle [45], vessel-associated pericytes [46], and blood [47]. Whether the quantity or quality of these particular cells varies with age remains to be determined [48]. 
Self-Renewal Capacity and MSC Potency with Advanced Age MSC are commonly expanded in culture. However, human MSC are not immortal in culture. One possible cellular aging mechanism is replicative or cellular senescence. In 1961, Hayflick and Moorhead [49] unveiled that human skin fibroblasts undergo only a limited number of population doublings in vitro (also termed 'Hayflick limit'), and furthermore this number decreases significantly with increasing donor age. Senescent fibroblasts produce elevated levels of molecules that are normally secreted in wound repair and infection, such as inflammatory cytokines, proteases and growth factors [50]. The latter may have detrimental consequences for the surrounding tissue and cells. The presence of senescent cells in vivo, which resemble cells having replicatively aged in culture and that eventually have become senescent, could indeed be observed in aged human skin $[51,52]$ as well as in the vascular system [53]. Thus, it is plausible that stem cells also reach an equivalent state of senescence in vivo. Evidence for this assumption is still missing while there is no doubt that replicative senescence of MSC occurs in vitro as demonstrated by a number of laboratories [18, 28, 35, 54-56]. The senescent phenotype of MSC includes the following characteristic features: irreversible arrest of cell division (in contrast to quiescence where this lock is reversible) and resistance to apoptotic death. Furthermore, MSC loose their differentiation potential at a pre-senescent state [18]. One explanation for replicative senescence emerging in stem cells is the down-regulation of telomerase enzyme activity [57]. The net impact is a successive telomere shortening with every cell division during DNA replication. The absence of telomerase activity in MSC and, as a result thereof, telomere attrition after extensive replication have been observed by many investigators $[16,58]$. Also various types of DNA damage and the expression of particular oncogenes can provoke cellular senescence. Furthermore, it is greatly believed that oxidative stress and other extrinsic influences that result from altered extracellular matrix and disturbed cell-cell and cell-matrix interactions can interfere with self-renewal of the stem cell. In turn this may lead to cellular aging and eventually results in cellular senescence. Last but not least, it is important to mention that chromatin remodelers, factors, which are well known to be required in the control of the cell cycle, apoptosis and differentiation processes, appear to negatively affect stem cell self-renewal properties. For example, the ATP-dependent remodeling complexes that contain Brg1 have been reported to be involved in the induction of MSC senescence [59].

As of now, there are no conclusive results available whether MSC in vivo also acquire a state comparable to the senescent phenotype in vitro and whether this is being induced through the above mentioned mechanisms. Most notably in the context of this review is that the maximum number of MSC population doublings and the proliferation rate of the initial passage of the primary MSC appear to be dependent on the age of the donors $[30,54,55,57]$. Only recently, we could show that the attenuated proliferation potential of MSC from aged donors greatly relies on the withdrawal of cells by cell death. Conclusively MSC pools, which display slowing growth kinetics, also contain an increasing number of dying cells, which is indicative for MSC accumulating during advancing age which fail to self-renew [60].

One peculiar feature of MSC is their capacity to escape immune recognition and their ability to suppress the activation of T cells. In vitro, MSC suppress lymphocyte alloreactivity in mixed lymphocyte cultures through a human leukocyte-independent mechanism [61-63]. Up to now, the potency of modulating immunological processes has for obvious reasons been confirmed and validated only in a limited number of experimental animal model systems [for a recent review see 64]. In the context of these findings, clinical trials have already been commenced in which MSC have been employed in the treatment of graft-versus-host disease (GvHD) [65]. Clearance of GvHD with third-party haploidentical MSC appears to be possible without side effects [66], and a phase II clinical study on steroid-resistant GvHD has been reported only recently [67]. Further examples in which MSC have been applied in a clinical setting are to enhance hematopoietic stem cell engraftment in the course of bone marrow transplantation [68], to correct inherited disorders of bone and cartilage [69], and/or to ameliorate tissue damage after myocardial infarction [70]. Also, attempts are being undertaken to employ MSC as vehicles for gene therapy, e.g. in osteogenesis imperfecta [71-73]. For a complete list of clinical indications presently being tested please refer to www.ClinicalTrial.gov. However, detailed clinical studies with special regard given to host and/or donor age have, to the best of our knowledge, not been undertaken yet.

\section{MSC and Age-Associated Disease}

Bone- and bone marrow-derived MSC are definitely a versatile cell source which can be employed to support tissue repair as well as to enhance regenerative processes (fig. 2). Working along these lines, it is generally believed that MSC have the potential to ameliorate or even cure age-related degenerative diseases. Thus, if implemented successfully, this may greatly improve the quality of life for elderly patients. However, certain limitations persist and call for careful quality control during therapy. Further studies are still needed in order to eliminate risk factors before putting MSC into clinical practice. Actually, the entire field of cell-based therapeutic intervention is confronted with issues related to this topic. These particularly include lacking experience with respect to long-term safety, the absence of standardized assays for quality control, and the still incomplete knowledge whether allogeneic MSC when applied in sick or elderly patients would also modulate the immune system efficiently $[64,69,74,75]$.

In this context major concerns are focusing on questions regarding the cell source, and of particular interest is the health status of the donor. As a showcase, Scaffidi and Mistelli [76]
302

Transfus Med Hemother 2008:35:299-305
Lepperdinger/Brunauer/Gassner/Jamnig/ Kloss/Laschober 


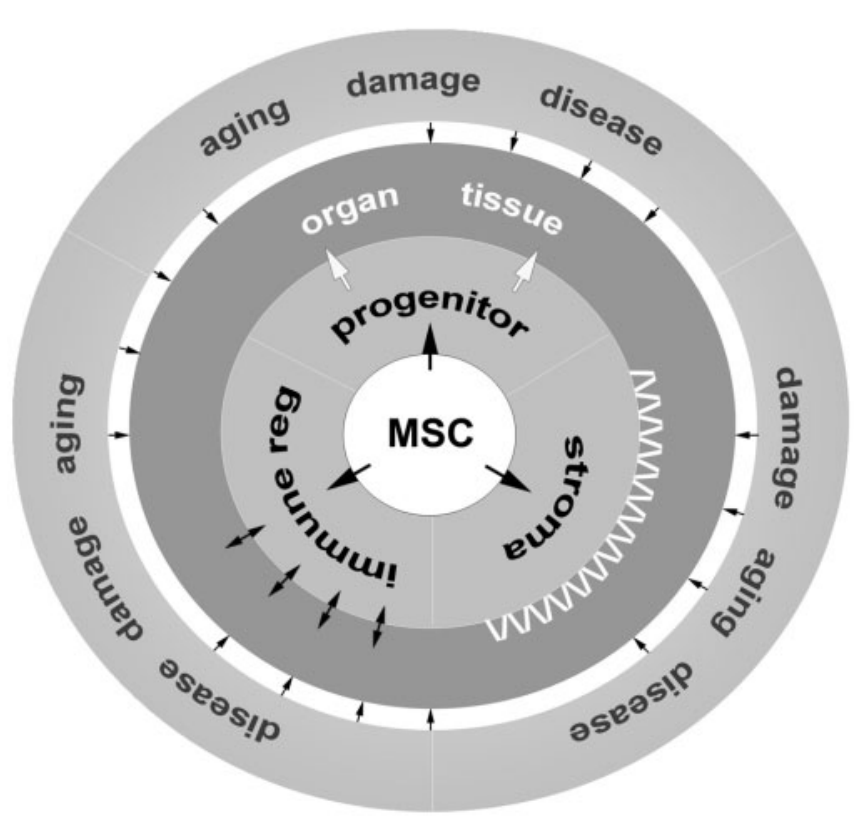

Fig. 2. Model of extrinsic feedback control on mesenchymal tissue regeneration by MSC progeny. MSC reside in their niches within mesenchymal tissues or organs. MSC are involved in regeneration and repair by bringing forth progenitor cells. In addition, MSC nurture stromal compartments with cells, which themselves are important regulators for stem cell renewal, in particular in the case of hematopoietic stem and precursor cells. Lastly, MSC exert immune modulatory properties. These processes are intricately dependent on the supervision of the niche which constantly undergoes changes not only because of cellular metabolic activity, but also due to pathologic insults, biological aging or tissue damage.

could recently show that MSC from patients who suffer from the pre-mature aging syndrome Hutchinson-Gilford disease show altered differentiation capacities. This observation suggests that impaired or altered stem cell potency may contribute to the reduced potential of tissue homeostasis and ultimately brings about an aged phenotype in an accelerated fashion [76].

The previous example refers to a disease, which is caused by a single factor, videlicet, an aberrant form of the nuclear architectural protein lamin A [77]. In contrast to that, the cause of age-associated pathologies such as osteoarthritis (OA) is not as well defined. OA is the most common rheumatologic disorder and affects over $70 \%$ of people over 65 years of age. Its etiology is not well understood $[78,79]$. It is generally accepted though that besides age multiple factors such as obesity, history of joint trauma, and joint dysplasia are involved. Joint resurfacing with tissue-engineered cartilage on the basis of isolated chondrocytes was shown to be greatly beneficial. The availability of chondrocytes however is a major constraint of such a therapy. In this respect, MSC represent an alternative cell source as they exhibit chondrogenic potential. However, there are contradicting results: Scharstuhl et al. [80] found no significant difference in numbers and differentiation potential when, irrespective of age or OA etiology, MSC have been isolated from OA patients, whereas Murphy et al. [81] observed a significant reduction of chondrogenic capacity. The latter is in line with data reported by Muschler et al. [32] earlier.

In the context of osteoporosis, another major age-associated health complication in which decreased bone formation resulting in bone loss is an important pathophysiological mechanism, the role of MSC aging is also not clearly defined yet. Stenderup et al. [37] showed that the number and the proliferative capacity of mesenchymal progenitor cells are maintained in patients with osteoporosis. In contrast, Rodriguez et al. [82] demonstrated that stem cell growth, proliferative response, and osteogenic differentiation of MSC from osteoporotic postmenopausal women are significantly affected. Since MSC are already employed to augment large bone defects by grafting engineered osseous tissue derived from explanted osteoprogenitors, specific means which clearly define those cellular properties may greatly enhance the outcome of these modern therapeutic strategies.

These few examples clearly show that it is presently not clear at all whether MSC which have been isolated from elderly (yet healthy) individuals can be safely implemented in clinical practice, primarily because aged organisms are faced, and this to a greatly varying extent, with the life-long accumulation of potentially deleterious impacts. Therefore, transplantation of naive stem cells, which are capable of producing progeny and which will actually continue to do so in situ post implantation, without careful examination of putative alterations of their cellular characteristics seems highly risky. Similar to other cell types, it is indispensable to perform extensive quality control for all MSC preparations to be employed in therapeutic applications. This has to include phenotypic, functional and genetic characterization. For the latter, many academic and clinical researchers are currently characterizing MSC by means of modern, state-of the art technologies. It can be anticipated that these unbiased data analyses, using genomic and proteomic methods, will elucidate distinct molecular parameters, which prognosticate the performance of individual MSC preparations, be it primary isolates or cells expanded in vitro.

\section{Concluding Remarks}

The prospective clinical use of MSC holds enormous promise for the treatment of a large number of degenerative and agerelated diseases. However, the challenges and risks for cellbased therapies are multifaceted. The theoretical health risk for patients receiving autologous MSC can hardly be anticipated, and the proper ways of manipulating the cells ex vivo are currently a matter of intensive investigation.

Careful pre-administration safety monitoring as well as close monitoring of the patients is essential for this novel form of therapy. Regulatory bodies such as the US Food and Drug administration [83] and the European Union (http://eur-lex. 
europa.eu/LexUriServ/site/en/oj/2007/l_324/__32420071210en01 210137.pdf) have recently established a set of regulations for cell-based therapeutics. The International Society for Stem Cell Research (ISSCR) has set up a 'task force on clinical translation of stem cells' (www.isscr.org/committees/committee Results.cfm? CommitteeName $=$ COMMITTEE/CLINTRANS) since more distinct directives are needed to progress effectively in translating this new technology into clinical practice. Only by continuous and open interactions between investigators, who provide appropriate analytical methodology and detailed understanding of the dynamic nature of stem cells, and research institutions that capitalize and endow peer-to-peer network environment and sustain complex logistics for clinical studies, together with regulatory bodies, efficient and safe cellbased therapies will become routine, in particular for patients suffering from age-associated diseases or frailty.

\section{Acknowledgements}

GL's work is supported by the Austrian Science Fund (FWF), NRN project S9305, by and by the Austrian Research Agency (FFG). RB is a DOC-fFORTE fellow of the Austrian Academy of Sciences (OeAW). RG greatly acknowledges the generous support by the Jubilee Fund of the Austrian National Bank (OeNB).

\section{References}

1 Horwitz EM, Le Blanc K, Dominici M, Mueller I, Slaper-Cortenbach I, Marini FC, Deans RJ, Krause DS, Keating A: Clarification of the nomenclature for MSC: The International Society for Cellular Therapy position statement. Cytotherapy 2005;7: 393-395.

2 Caplan AI: Mesenchymal stem cells. J Orthop Res 1991;9:641-650.

3 Pittenger MF, Mosca JD, McIntosh KR: Human mesenchymal stem cells: progenitor cells for cartilage, bone, fat and stroma. Curr Top Microbiol Immunol 2000;251:3-11.

4 Prockop DJ, Sekiya I, Colter DC: Isolation and characterization of rapidly self-renewing stem cells from cultures of human marrow stromal cells. $\mathrm{Cy}$ totherapy 2001;3:393-396.

5 Gronthos S, Graves SE, Ohta S, Simmons PJ: The STRO-1+ fraction of adult human bone marrow contains the osteogenic precursors. Blood 1994;84: 4164-4173.

6 Horwitz EM, Keating A: Nonhematopoietic mesenchymal stem cells: what are they? Cytotherapy 2000;2:387-388.

7 Dominici M, Le Blanc K, Mueller I, Slaper-Cortenbach I, Marini F, Krause D, Deans R, Keating A, Prockop D, Horwitz E: Minimal criteria for defining multipotent mesenchymal stromal cells. The International Society for Cellular Therapy position statement. Cytotherapy 2006;8:315-317.

8 Rando TA: Stem cells, ageing and the quest for immortality. Nature 2006;441:1080-1086.

9 Campagnoli C, Roberts IA, Kumar S, Bennett PR Bellantuono I, Fisk NM: Identification of mesenchymal stem/progenitor cells in human firsttrimester fetal blood, liver, and bone marrow. Blood 2001;98:2396-2402.

10 Tsai MS, Lee JL, Chang YJ, Hwang SM: Isolation of human multipotent mesenchymal stem cells from second-trimester amniotic fluid using a novel two-stage culture protocol. Hum Reprod 2004;19: 1450-1456.

11 In 't Anker PS, Scherjon SA, Kleijburg-van der Keur C, de Groot-Swings GM, Claas F H, Fibbe WE, Kanhai HH: Isolation of mesenchymal stem cells of fetal or maternal origin from human placenta. Stem Cells 2004;22:1338-1345.

12 Mareschi K, Biasin E, Piacibello W, Aglietta M, Madon E, Fagioli F: Isolation of human mesenchymal stem cells: bone marrow versus umbilical cord blood. Haematologica 2001;86:1099-1100.

13 Gotherstrom C, West A, Liden J, Uzunel M, Lahesmaa R, Le Blanc K: Difference in gene expression between human fetal liver and adult bone marrow mesenchymal stem cells. Haematologica 2005;90: 1017-1026.
14 Mirmalek-Sani SH, Tare RS, Morgan SM, Roach HI, Wilson DI, Hanley NA, Oreffo RO: Characterization and multipotentiality of human fetal femurderived cells: implications for skeletal tissue regeneration. Stem Cells 2006;24:1042-1053.

15 Friedenstein AJ, Piatetzky SI, Petrakova KV: Osteogenesis in transplants of bone marrow cells. J Embryol Exp Morphol 1966;16:381-390.

16 Pittenger MF, Mackay AM, Beck SC, Jaiswal RK, Douglas R, Mosca JD, Moorman MA, Simonetti DW, Craig S, Marshak DR: Multilineage potential of adult human mesenchymal stem cells. Science 1999;284:143-147.

17 Pereira RF, Halford KW, O'Hara MD, Leeper DB, Sokolov BP, Pollard MD, Bagasra O, Prockop DJ: Cultured adherent cells from marrow can serve as long-lasting precursor cells for bone, cartilage, and lung in irradiated mice. Proc Natl Acad Sci U S A 1995;92:4857-4861.

18 Fehrer C, Brunauer R, Laschober G, Unterluggauer H, Reitinger S, Kloss F, Gülly C, Gassner R, Lepperdinger $\mathrm{G}$ : Reduced oxygen tension attenuates differentiation capacity of human mesenchymal stem cells and prolongs their lifespan. Aging Cell 2007;6:745-757.

19 Tuli R, Tuli S, Nandi S, Wang ML, Alexander PG, Haleem-Smith H, Hozack WJ, Manner PA, Danielson KG, Tuan RS: Characterization of multipotential mesenchymal progenitor cells derived from human trabecular bone. Stem Cells 2003;21: 681-693.

20 Schaffler A, Buchler C: Concise review: adipose tissue-derived stromal cells - basic and clinical implications for novel cell-based therapies. Stem Cells 2007;25:818-827.

21 Nakahara H, Bruder SP, Goldberg VM, Caplan AI: In vivo osteochondrogenic potential of cultured cells derived from the periosteum. Clin Orthop Relat Res 1990:223-232.

22 Sakaguchi Y, Sekiya I, Yagishita K, Muneta T: Comparison of human stem cells derived from various mesenchymal tissues: superiority of synovium as a cell source. Arthritis Rheum 2005;52:2521-2529. 23 Abedin M, Tintut Y, Demer LL: Mesenchymal stem
cells and the artery wall. Circ Res 2004;95:671-676.

24 Zhang W, Walboomers, XF, Shi S, Fan M, Jansen JA: Multilineage differentiation potential of stem cells derived from human dental pulp after cryopreservation. Tissue Eng;2006, 12:2813-23.

25 Arthur A, Rychkov G, Shi S, Koblar SA, Gronthos S: Adult human dental pulp stem cells differentiate towards functionally active neurons under appropriate environmental cues. Stem Cells, 2008; DOI: 10.1634/stemcells.2007-0979.
26 Young HE, Steele TA, Bray RA, Hudson J, Floyd JA, Hawkins K, Thomas K, Austin T, Edwards C, Cuzzourt J, Duenzl M, Lucas PA, Black AC Jr: Human reserve pluripotent mesenchymal stem cells are present in the connective tissues of skeletal muscle and dermis derived from fetal, adult, and geriatric donors. Anat Rec 2001;264:51-62.

27 Roufosse CA, Direkze NC, Otto WR, Wright NA Circulating mesenchymal stem cells. Int J Biochem Cell Biol 2004;36:585-597.

28 Kern S, Eichler H, Stoeve J, Kluter H, Bieback K: Comparative analysis of mesenchymal stem cells from bone marrow, umbilical cord blood, or adipose tissue. Stem Cells 2006;24:1294-1301.

29 Guillot PV, O'Donoghue K, Kurata H, Fisk NM: Fetal stem cells: betwixt and between. Semin Reprod Med 2006;24:340-347.

30 Baxter MA, Wynn RF, Jowitt SN, Wraith JE, Fairbairn LJ, Bellantuono I: Study of telomere length reveals rapid aging of human marrow stromal cells following in vitro expansion. Stem Cells 2004; 22675-682.

31 Nishida S, Endo N, Yamagiwa H, Tanizawa T, Takahashi HE: Number of osteoprogenitor cells in human bone marrow markedly decreases after skeletal maturation. J Bone Miner Metab 1999;17: 171-177.

32 Muschler GF, Nitto H, Boehm CA, Easley KA: Age- and gender-related changes in the cellularity of human bone marrow and the prevalence of osteoblastic progenitors. J Orthop Res 2001;19:117125.

33 Majors AK, Boehm CA, Nitto H, Midura RJ, Muschler GF: Characterization of human bone marrow stromal cells with respect to osteoblastic differentiation. J Orthop Res 1997;15:546-557.

34 Caplan AI: Adult mesenchymal stem cells for tissue engineering versus regenerative medicine. J Cell Physiol 2007;213:341-347.

35 Stolzing A, Jones E, McGonagle D, Scutt A: Agerelated changes in human bone marrow-derived mesenchymal stem cells: consequences for cell therapies. Mech Ageing Dev 2008;129:163-173.

36 Oreffo RO, Bennett A, Carr AJ, Triffitt JT: Patients with primary osteoarthritis show no change with ageing in the number of osteogenic precursors. Scand J Rheumatol 1998;27:415-424.

37 Stenderup K, Justesen J, Eriksen EF, Rattan SI, Kassem M: Number and proliferative capacity of osteogenic stem cells are maintained during aging and in patients with osteoporosis. J Bone Miner Res 2001;16:1120-1129. 
\38 Justesen J, Stenderup K, Eriksen EF, Kassem M: Maintenance of osteoblastic and adipocytic differentiation potential with age and osteoporosis in human marrow stromal cell cultures. Calcif Tissue Int 2002;71:36-44.

>39 D'Ippolito G, Schiller PC, Ricordi C, Roos BA, Howard GA: Age-related osteogenic potential of mesenchymal stromal stem cells from human vertebral bone marrow. J Bone Miner Res 1999;14:11151122.

40 Glowacki J: Influence of age on human marrow. Calcif Tissue Int 1995;56(suppl 1):S50-51.

41 Kuznetsov SA, Krebsbach PH, Satomura K, Kerr J, Riminucci M, Benayahu D, Robey PG: Singlecolony derived strains of human marrow stromal fibroblasts form bone after transplantation in vivo. $\mathrm{J}$ Bone Miner Res 1997;12:1335-1347.

42 Muraglia A, Cancedda R, Quarto R: Clonal mesenchymal progenitors from human bone marrow differentiate in vitro according to a hierarchical model. J Cell Sci 2000;113:1161-1166.

43 Zhou S, Greenberger JS, Epperly MW, Goff JP, Adler C, Leboff MS, Glowacki J: Age-related intrinsic changes in human bone-marrow-derived mesenchymal stem cells and their differentiation to osteoblasts. Aging Cell 2008;7:335-343.

44 Mueller SM, Glowacki J: Age-related decline in the osteogenic potential of human bone marrow cells cultured in three-dimensional collagen sponges. J Cell Biochem 2001;82:583-590.

45 Bosch P, Musgrave DS, Lee JY, Cummins J, Shuler T, Ghivizzani TC, Evans T, Robbins TD, Huard J: Osteoprogenitor cells within skeletal muscle. J Orthop Res 2000;18:933-944.

46 Collett GD, Canfield AE: Angiogenesis and pericytes in the initiation of ectopic calcification. Circ Res 2005;96:930-938.

47 Eghbali-Fatourechi GZ, Lamsam J, Fraser D, Nage D, Riggs BL, Khosla S: Circulating osteoblast-lineage cells in humans. N Engl J Med 2005;352: 1959-1966.

48 Gruber R, Koch H, Doll BA, Tegtmeier F, Einhorn TA, Hollinger JO: Fracture healing in the elderly patient. Exp Gerontol 2006;41:1080-1093.

49 Hayflick L, Moorhead PS: The serial cultivation of human diploid cell strains. Exp Cell Res 1961;25: 585-621.

50 Campisi J: From cells to organisms: can we learn about aging from cells in culture? Exp Gerontol 2001;36:607-618.

-51 Dimri GP, Lee X, Basile G, Acosta M, Scott G, Roskelley C, Medrano EE, Linskens M, Rubelj I, Pereira-Smith O, Peacocke M, Campisi J: A biomarker that identifies senescent human cells in culture and in aging skin in vivo. Proc Natl Acad Sci U S A 1995;92:9363-9367.

- 52 Ressler S, Bartkova J, Niederegger H, Bartek J, Scharffetter-Kochanek K, Jansen-Dürr P, Wlaschek M: p16INK4A is a robust in vivo biomarker of cellular aging in human skin. Aging Cell 2006;5 379-389.

53 Vasile E, Tomita Y, Brown LF, Kocher O, Dvorak HF: Differential expression of thymosin beta- 10 by early passage and senescent vascular endothelium is modulated by VPF/VEGF: evidence for senescent endothelial cells in vivo at sites of atherosclerosis. FASEB J 2001;15:458-466.

54 Digirolamo CM, Stokes D, Colter D, Phinney DG, Class R, Prockop DJ: Propagation and senescence of human marrow stromal cells in culture: a simple colony-forming assay identifies samples with the greatest potential to propagate and differentiate. Br J Haematol 1999;107:275-281.
55 Stenderup K, Justesen J, Clausen C, Kassem M: Aging is associated with decreased maximal life span and accelerated senescence of bone marrow stromal cells. Bone 2003;33:919-926.

56 Stenderup K, Rosada C, Justesen J, Al-Soubky T, Dagnaes-Hansen F, Kassem M: Aged human bone marrow stromal cells maintaining bone forming capacity in vivo evaluated using an improved method of visualization. Biogerontology 2004;5:107-118.

57 Forsyth NR, Wright WE, Shay JW: Telomerase and differentiation in multicellular organisms: turn it off, turn it on, and turn it off again. Differentiation 2002;69:188-197.

58 Zimmermann S, Voss M, Kaiser S, Kapp U, Waller CF, Martens UM: Lack of telomerase activity in human mesenchymal stem cells. Leukemia 2003;17: 1146-1149.

59 Napolitano MA, Cipollaro M, Cascino A, Melone MA, Giordano A, Galderisi U: Brg1 chromatin remodeling factor is involved in cell growth arrest, apoptosis and senescence of rat mesenchymal stem cells. J Cell Sci 2007;120:2904-2911.

60 Laschober G, Brunauer R, Jamnig A, Fehrer C, Greiderer B, Lepperdinger G: Leptin receptor/CD 295 is upregulated on primary human mesenchymal stem cells of advancing biological age and distinctly marks the subpopulation of dying cells. Exp Gerontol 2008;DOI: 10.1016/j.exger.2008.05.013.

61 Bartholomew A, Sturgeon C, Siatskas M, Ferrer K, McIntosh K, Patil S, Hardy W, Devine S, Ucker D, Deans R, Moseley A, Hoffman R: Mesenchymal stem cells suppress lymphocyte proliferation in vitro and prolong skin graft survival in vivo. Exp Hematol 2002;30:42-48.

62 Krampera M, Glennie S, Dyson J, Scott D, Laylor R, Simpson E, Dazzi F: Bone marrow mesenchymal stem cells inhibit the response of naive and memory antigen-specific $\mathrm{T}$ cells to their cognate peptide. Blood 2003;101:3722-3729.

63 Le Blanc K, Tammik C, Rosendahl K, Zetterberg E, Ringden O: HLA expression and immunologic properties of differentiated and undifferentiated mesenchymal stem cells. Exp Hematol 2003;31: 890-896.

64 Le Blanc K, Ringden O: Immunomodulation by mesenchymal stem cells and clinical experience. J Intern Med 2007;262:509-525.

65 Ringden O, Uzunel M, Rasmusson I, Remberger M, Sundberg B, Lonnies H, Marschall HU, Dlugosz A, Szakos A, Hassan Z, Omazic B, Aschan J, Barkholt L, Le Blanc K: Mesenchymal stem cells for treatment of therapy-resistant graft-versus-host disease. Transplantation 2006;81:1390-1397.

66 Le Blanc K, Rasmusson I, Sundberg B, Gotherstrom C, Hassan M, Uzunel M, Ringden O: Treatment of severe acute graft-versus-host disease with third party haploidentical mesenchymal stem cells. Lancet 2004:363:1439-1441.

67 Le Blanc K, Frassoni F, Ball L, Locatelli F, Roelofs $\mathrm{H}$, Lewis I, Lanino E, Sundberg B, Bernardo ME, Remberger M, Dini G, Egeler RM, Bacigalupo A, Fibbe W, Ringden O: Mesenchymal stem cells for treatment of steroid-resistant, severe, acute graftversus-host disease: a phase II study. Lancet 2008; 371:1579-1586.

68 Giordano A, Galderisi U, Marino IR: From the laboratory bench to the patient's bedside: an update on clinical trials with mesenchymal stem cells. J Cell Physiol 2007;211:27-35.
69 Bolland BJ, Tilley S, New AM, Dunlop DG, Oreffo RO: Adult mesenchymal stem cells and impaction grafting: a new clinical paradigm shift. Expert Rev Med Devices 2007;4:393-404.

70 Abdel-Latif A, Bolli R, Tleyjeh IM, Montori VM, Perin EC, Hornung CA, Zuba-Surma EK, Al-Mal lah M, Dawn B: Adult bone marrow-derived cells for cardiac repair: a systematic review and metaanalysis. Arch Intern Med 2007;167:989-997.

71 Horwitz EM, Prockop DJ, Fitzpatrick LA, Koo WW, Gordon PL, Neel M, Sussman M, Orchard P Marx JC, Pyeritz RE, Brenner MK: Transplantability and therapeutic effects of bone marrow-derived mesenchymal cells in children with osteogenesis imperfecta. Nat Med 1999:5:309-313.

72 Chamberlain JR, Deyle DR, Schwarze U, Wang P Hirata RK, Li Y, Byers PH, Russell DW: Gene targeting of mutant COL1A2 alleles in mesenchymal stem cells from individuals with osteogenesis imperfecta. Mol Ther 2008;16:187-193.

73 Pochampally RR, Horwitz EM, DiGirolamo CM Stokes DS, Prockop DJ: Correction of a mineralization defect by overexpression of a wild-type cDNA for COL1A1 in marrow stromal cells (MSCs) from a patient with osteogenesis imperfecta: a strategy for rescuing mutations that produce dominant-negative protein defects. Gene Ther 2005;12:11191125

74 Kassem M: Stem cells: potential therapy for agerelated diseases. Ann N Y Acad Sci 2006:1067:436442.

75 Abdallah BM, Kassem M: Human mesenchymal stem cells: from basic biology to clinical applications. Gene Ther 2008;15:109-116.

76 Scaffidi P, Misteli T: Lamin A-dependent misregulation of adult stem cells associated with accelerated ageing. Nat Cell Biol 2008;10:452-459.

77 Eriksson M, Brown WT, Gordon LB, Glynn MW, Singer J, Scott L, Erdos MR, Robbins CM, Mose TY, Berglund P, Dutra A, Pak E, Durkin S, Csoka AB, Boehnke M, Glover TW, Collins FS: Recurren de novo point mutations in lamin A cause Hutchinson-Gilford progeria syndrome. Nature 2003;423: 293-298.

78 Ferretti M, Gassner R, Wang Z, Perera P, Deschner J, Sowa G, Salter RB, Agarwal S: Biomechanical signals suppress proinflammatory responses in cartilage: early events in experimental antigen-induced arthritis J Immunol 2006;177:8757-8766.

79 Creamer P, Hochberg MC: Osteoarthritis. Lancet 1997;350:503-508.

80 Scharstuhl A, Schewe B, Benz K, Gaissmaier C, Buhring HJ, Stoop R: Chondrogenic potential of human adult mesenchymal stem cells is independent of age or osteoarthritis etiology. Stem Cells 2007;25:3244-3251.

81 Murphy JM, Dixon K, Beck S, Fabian D, Feldman A, Barry F: Reduced chondrogenic and adipogenic activity of mesenchymal stem cells from patients with advanced osteoarthritis. Arthritis Rheum 2002;46:704-713.

82 Rodriguez JP, Garat S, Gajardo H, Pino AM, Seitz $\mathrm{G}$ : Abnormal osteogenesis in osteoporotic patient is reflected by altered mesenchymal stem cells dynamics. J Cell Biochem 1999:75:414-423.

83 Halme DG, Kessler DA: FDA regulation of stemcell-based therapies. N Engl J Med 2006:355:17301735 . 